\title{
Negative Health Review of Cell Phones and Social Media
}

\author{
Danielle M. Viola* \\ Tranquil Tides Mental Health \& Wellness, LLC, USA
}

Article Info

\section{Article Notes}

Received: February 19, 2021

Accepted: March 19, 2021

\section{${ }^{*}$ Correspondence:}

Danielle M. Viola, Tranquil Tides Mental Health \& Wellness,

LLC, 12 Parmenter Road, Suite A3, Londonderry, New

Hampshire 03053, USA; Email: midushi123@yahoo.com.

(c) 2021 Viola DM. This article is distributed under the terms of the Creative Commons Attribution 4.0 International License.

\section{Keywords:}

Cell phones and mental health Social media and mental health Cell phones and physical health Social media and physical health Negative effects of cell phones Negative effects of social media
Abstract

Cell phone and social media usage have become intriguing topics to explore and discuss over recent years. This research aims to review correlations of negative effects in mental and physical health caused by cell phone and social media use in the past two decades. The history of cell phones and their capabilities will be introduced. The need for human connection will be emphasized. Exploration of the connection between unbalanced use and different aspects of health will be evaluated such as addiction, social influences, brain changes, and multitasking. Lastly, resources and recommendations to find balance and support for anyone being adversely affected by cell phones and social media will be provided. Current literature reveals that there is a negative correlation between increased cell phone and social media use with human connection, mental health, and physical health.

\section{Introduction}

Cell phones have greatly evolved in the past 50 years. The DynaTAC 8000X, was the first cell phone allowing only telephone calls and was invented in 1973 by Martin Cooper, an executive at Motorola $^{16}$. Smartphones are high performance cell phones and essentially mini mobile computers that include high definition (HD) calls, photos and video, texting, cloud storage, increased battery life, and thousands of available applications ${ }^{6}$. According to the Pew Research Center's latest national survey, 96\% of Americans own a cell phone and $81 \%$ own a smartphone $\mathrm{e}^{52}$. As popularity has grown, so has the integration of these devices into culture and interpersonal relationships. Time Magazine along with Qualcomm surveyed 4,700 people online and 300 by phone around the globe in 2012. They found that $35 \%$ of North America, $43 \%$ of Brazil, $40 \%$ of China, $44 \%$ of India, $26 \%$ of South Korea, and $34 \%$ of United Kingdom use their cell phone while playing with their kids. Also, $36 \%$ of North America, $56 \%$ of Brazil, $70 \%$ of China, $71 \%$ of India, $56 \%$ of South Korea, and $26 \%$ of United Kingdom use their cell phone while going out to eat at a restaurant. Out of all the participants aged 2529 years-old, 55\% had sent suggestive pictures and $36 \%$ used cell phones to coordinate adultery ${ }^{18}$. Screen Education, an investigative organization of technology and human wellness, revealed that $58 \%$ of teenagers feel immediate response to notifications is necessary, $33 \%$ spend more time socializing online rather than in person, $69 \%$ wished they socialize more live than online, and $52 \%$ believe that too much silent time is spent on phones when with friends. These results came after a nine-minute, survey interviewing 1,017 adolescents between the ages of 13-18 from 2016-2018 ${ }^{59}$. These statistics expose some expectations of cell phone and social media culture and provide a glimpse of negative effects on mental and physical health. 


\section{Method}

A pointed search of literature identifying problems relating areas of poor health to social media and cell phone use were examined. Summaries of the findings were analyzed and presented in this article. The databases used to obtain research articles for review included Google Scholar, NIH, Research Gate, Semantic Scholar, and PubMed. The search terms used to gather information included: meta-analysis on social relationships and health; emotional deprivation and development; exclusion and brain studies; loneliness and addiction to cell phones; depression and media screen time; mobile phone dependence and brain studies; adolescent screen time and brain development; distracted parents from mobile devices and infant response; preteen non-verbal recognition and screen media; cognitions and multitasking with social media; evening light from screens and sleep; thumb pain and texting; and, neck pain and increased cell phone use. The analysis involved meta-analytical reviews, original studies, observational studies, mass surveys, and interviews. Where possible, basic statistical data was presented to substantiate claims concerning negative effects from social media and cell phone use.

\section{Need for Human Connection}

In a meta-analysis, Holt-Lunstad, Smith, and Layton $(2010)^{26}$ reviewed 148 studies with over 300,000 participants that analyzed how social relationships influence the risk of mortality. Amount of social integration, perception of social support received from social interaction, and the actual amount of social support available was assessed and controlled in accordance with risk factors such as lifestyle and disease. Complex measures of social integration were evaluated by participant questionnaires. These results were then used to assess the degree of association between social relationships and mortality between studies, and structural and functional aspects of social relationships. These outcomes revealed that there were stronger associations between social relationships and mortality (Odds Ratio $(\mathrm{OR})=1.91$ ) compared to those studies that only included binary measures such as married versus being single $(O R=1.19)$. Statistical significance was demonstrated at a $95 \%$ confidence interval across the types of measures used $(\mathrm{p}<0.001)$, and the average random effects for multidimensional assessments was $\mathrm{OR}=1.5$. These statistics explain that survival was $50 \%$ more likely with stronger social relationships than with weaker social relationships. Other poignant conclusions were found when these researchers compared their average weighted random effects results to other metaanalyses linking various conditions to mortality rates. They concluded that mortality as a function of a lack of social relationships $(\mathrm{OR}=1.5)$ is comparable to mortality rates of those drinking six or more alcohol drinks per day (average $\mathrm{OR}=1.45$ ), smoking 15 cigarettes per day (OR= $1.52)$ and are twice as deadly when compared to obesity $(\mathrm{OR}=0.80)^{26}$.

An orphanage study in the 1940's adds credence to the detrimental effects of loneliness. In 1945 Spitz and Wolf observed 61 infants from birth to 18 months in foundling homes with no maternal influence and compared them to 69 infants of the same age in a women's prison who interacted with their mothers. Between 6-18 months, babies entered stages of social and physical withdrawal in the foundling homes, where in the women's prison, babies actively engaged with the mothers. In the foundling homes, infants from six to eight months demonstrated weepiness which eventually led to withdrawal ${ }^{61,63,50}$. Spitz and Wolf defined their observation of withdrawal by children losing weight, insomnia, eczema, averting their face and refusing to respond ${ }^{63}$. In a two year follow up report, Spitz $(1946)^{63}$ concluded that $37 \%$ of the foundling infants died while all the prison babies survived and thrived to the point of reaching normal development in the areas of motor movement, growth, and speech. Out of the 21 remaining living children in foundling homes, only two fell into the normal height range and only five were able to walk without assistance. Although there were no formal statistical tests to measure the data, Spitz's observations provided some insight that mortality increased as the length of time without mothers increased ${ }^{13,62}$. These results support the idea that a child's ability to thrive physically and emotionally depends on the presence or absence of socialization with others, particularly the mother.

Another study by Eisenberger, Liebermain, and Williams $(2003)^{17}$ described the importance of social inclusion by testing exclusion. This experiment involved 13 participants connected to a functional Magnetic Resonance Imaging (fMRI) machine and observed how each participant responded to being excluded from a game of catch. The subjects were instructed to interact with two remote live players, but the other two players were computer simulated and controlled to create distress. During the experiment, the live participants were isolated from the simulated players. After 10 times of taking turns throwing the ball, the simulated players ignored each of the live participants by throwing the ball only to each other. After being excluded for 45 throws, each participant completed a questionnaire measuring their distress. The amount of distress reported by each of the participants correlated with the amount of activation viewed on the fMRIs in the areas of the brain that sense physical pain (i.e. anterior cingulated cortex) and more specifically affective pain (i.e. dorsal anterior cingulated cortex). This research exemplifies how important it is to feel included ${ }^{17}$. 


\section{Mental Health}

\section{Loneliness, Depression, and Anxiety}

Smartphone addiction has been linked to loneliness. A study by Bian and Leung (2014) $)^{11}$ surveyed 414 Chinese university students by using two validated scales: the revised UCLA Loneliness Scale and the Smartphone Addictions Scale (SPAS). Five addiction symptoms were included: (1) disregarding negative consequences; (2) preoccupation; (3) inability to control behavior; (4) productivity loss and feeling lost; and (5) anxiousness. The results reported that loneliness scale answers were directly proportional to smartphone addiction symptoms. The lonelier someone felt, the more likely they were addicted to their smartphone ${ }^{11}$.

Jean Twenge, PhD, a psychologist and professor of psychology at San Diego State University, reviewed data and surveys of generational differences from the 1950's until 2014. She explains that the suicide rate for children under 14 doubled in 2014 from $1980^{66}$. Additionally, according to the National Electronic Injury Surveillance System-All Injury Program, emergency room visits for self-harm have tripled among girls aged 10-14 years old from 2009-2015 ${ }^{37}$. After finding these statistics, Twenge et al. $(2017)^{67}$ wanted to find reasons for such dramatic increases. They gathered reported data from two nationally represented surveys: Monitoring the Future (MtF) $(388,275$ participants $)$ and Youth Risk Behavior Surveillance System (YRBSS) $(118,545)$, and cross referenced this information with the Centers for Disease Control and Preventions (CDC) data per 100,000 population on suicide deaths since 1999 . They compared frequency of using new media screen time (electronic devices: cell phones, computers, video games, social media), older media screen time (television), and non-media screen time (playing outdoors, in-person social interaction, homework, etc.). The researchers noticed shifts of leisure time since 1999. As frequency of new media screen time increased from 2009-2015, television and nonmedia screen time decreased. Of the six items assessing depression from the MtF report, a mean item score of three or more signified concern for teen depression. The feelings assessed included hope, usefulness, enjoyment, meaning, appreciation of life, and ability to perform well in general. They found that in 2015, a mean score of at least three was reported 33\% more since 2009 and adolescents (13-18 years old) who spent six hours or more on their electronic devices were $66 \%$ more likely to respond as having at least one suicide-related event (i.e. suicidal attempt, plan, or ideation). The results demonstrated that there was a significant correlation between depression and social media use (Internet, YouTube, and social networking sites such as Facebook) among girls ( $\mathrm{r}=0.06, \mathrm{p}<0.001)$, but not boys $(r=0.01, p<0.08)$. Although, all suicide related outcomes measured were significantly correlated with electronic device use despite gender (average $\mathrm{r}=0.09$, $\mathrm{p}<$ $0.001)$. These results infer that boys are less likely to report depressive symptoms than girls despite having suicide related events reported in the survey questionnaires. Also, the researchers concluded that despite gender differences, increases in reported depressive symptoms and suicidal ideation were positively correlated with increases in all screen time activities (including television and gaming) and negatively correlated with all non-screen time activities ${ }^{67}$. More research needs to be done to learn about the social media habits of adolescent boys.

Nancy Jo Sales, an American journalist, interviewed 200 teen girls from across the country with a varying range of demographics and observed that popularity was determined by likes on social media. She noticed that when the number of likes increased, pressure to sustain or improve these numbers also increased. If someone receives a low number of likes, they are judged as unpopular by peers and are more likely to be bullied ${ }^{57}$. Texting (chatting) is another form of communication in social media. However, typed text can be misinterpreted due to lack of nonverbal cues and intonation such as sarcasm, sadness, or anger ${ }^{32}$. These interpretations can influence social connections as well as likes. Examples of misleading texts that could be misinterpreted include giving one-word answers without elaborating or leaving someone's message unread ${ }^{29}$. Screen Education researchers found that out of the $82 \%$ of the American teenage population that owns a cell phone, $42 \%$ are fearful of being gossiped about online ${ }^{59}$. These sources indicate that symptoms of anxiety and depression are more evident with increased cell phone use, but more studies need to be done to correlate what motivates someone to increase their frequency of using their cell phone and how that motivation leads to depression or anxiety.

\section{Cyberbullying and Self-Harm}

According to the Cyberbullying Research Center, cyberbullying is defined as "willful and repeated harm inflicted through the use of computers, cell phones, and other electronic devices"25. Insult generator applications (apps) such as Ugly Meter and Enemy Graph have been designed to rate others in negative ways and allow insults to be sent to targeted individuals. Ugly Meter has over 5,000,000 downloads. This app rates uploaded pictures based on physical appearance markers. Enemy Graph is used on Facebook to determine who is an enemy or archenemy based on the user's opinion. This rating is seen by anyone who views the page. Anonymous texting is another app which allows someone to send messages without being identified. These apps contribute to cyberbullying by encouraging the sending of negative opinions or messages that may or may not be true ${ }^{24}$. Apps on cell phones and computers are only one method that cyberbullies use. 
Patchin and Hinduja (2019) ${ }^{48}$ surveyed over 200,000 students from 98 middle schools and high schools throughout the United States from 2002 to 2019. The survey included questions regarding hurtful comments, harmful pictures or videos sent or received, posted threats and rumors on social media, and imposter websites or texts where the bully pretends to be someone else to fool the victim. They found that $27 \%$ of those surveyed have been cyberbullied in their lifetime and $10 \%$ were cyberbullied within 30 days of their survey. Also, 16\% of those cyberbullied, did it to someone else in their lifetime and $6 \%$ did so within 30 days of the survey. They concluded that one out of four teens are cyberbullied, and one out of six teens have cyberbullied someone else ${ }^{48}$.

Several cases of cyberbullying have been the cause of attention in recent years. The first nationally recognized and documented cyberbullying case involved Ryan Halligan, a 13-year-old middle school student, who was cyberbullied by his peers. He was initially bullied in elementary school because of his disabilities. In middle school, some fellow students deceived him into thinking they were friends. They spread rumors that he was gay and copied and pasted personal information, sending it to several classmates. Ryan hung himself on October 7, 2003 ${ }^{14}$. Ryan's suicide led his father, John Halligan, to begin working on establishing anti-bullying laws such as: The Bullying Prevention Policy Law, Act 117 (2004) and The Suicide Prevention Law, Act $114(2006)^{64}$.

Publicly posting to unknown viewers with thoughts of creating friendships or romance may lead to exploitation or predator activity. In October of 2012, a 15-year-old high school student, Amanda Todd, created a video before ending her life, explaining her experience with a man she met online. He started complementing her and then asking her for nude pictures. At first, she obliged but then refused. He blackmailed her and eventually shared her intimate pictures to her friends on Facebook. Amanda tried to cope with her shame, fear, and helplessness by turning to drugs, alcohol, and sex. After her friends ostracized her, Amanda felt lonely and hopeless and suicided ${ }^{15}$.

The latest high-profile case was Conrad Roy III who suicided after hundreds of text messages were found between him and his girlfriend, Michelle Carter, who urged him to go ahead with his suicide plan ${ }^{58}$. These case studies are examples of how cyberbullying contributes to demeaning other's self-worth, which has led to loneliness, withdrawal, isolation, depressed mood, and suicidal ideation; all of which are symptoms of Major Depression ${ }^{5}$.

\section{Cell Phone Use and Physiology}

The Screen Education survey revealed that $80 \%$ of teens typically spend time on their phone after they go to bed, but before falling asleep and of those, $22 \%$ of teens spend 30-60 minutes on their phone before falling asleep, $18 \%$ spend $1-2$ hours, $11 \%$ spend $2-3$ hours, and $11 \%$ spend more than 3 hours before falling asleep ${ }^{59}$. Researchers from the National Sleep Foundation surveyed 1,508 American people in 2011 between the ages of 1364. The participants were grouped according to their generation. Part of the survey questioned cell phone use one hour before bed, coping strategies for sleepiness, and driving drowsy statistics. Results demonstrated that 58\% of those surveyed used cell phones in some way before bed (e.g. texting, internet browsing, checking emails, watching videos, etc.). Additionally, an average of $74 \%$ used caffeinated beverages as a coping skill for sleepiness and $44 \%$ took naps every day. Within the subgroups, $72 \%$ of participants aged 13-18 used their cell phone one hour before bed and $61 \%$ get less than eight hours of sleep per night. Among participants aged 19-29, 67\% used their cell phone one hour before bed and $66 \%$ admitted to driving while drowsy ${ }^{20,44}$. These percentages represent the growing problem with increased cell phone use. People are becoming more tired, less focused, and more dangerous on the road.

Insomnia and eye problems from blue light emissions have been associated with increased cell phone use according to the National Sleep Foundation. One contributing factor to insomnia is the sleep/wake cycle, or circadian rhythm, being disrupted from blue light emitted from phones during use in evening hours. Blue light delays the natural production of melatonin which is the chemical needed to signal the body that it is time for sleep ${ }^{43}$. Melatonin helps prepare the body for sleep by dropping the body temperature and reducing cortisol levels. Blue light fatigues the muscles in the eyes due to its shorter wavelengths compared to other light, which can lead to eye strain, pain, and even damage to the cornea ${ }^{65}$.

Sleep quality was compared to different wavelengths and intensities of light in a study at the University of Haifa. Three physiological measures taken. The polysomnography measured physical changes during sleep such as brain wave activity, heart rate, breathing rate, etc. Melatonin levels through urine samples and body temperature were taken at various times throughout the study. There were also three behavioral tests that measured daytime sleepiness, physical and emotional symptoms, and inattention and impulsivity. The most significant findings of this study were that short wave blue light independently disrupted the ability of the body to produce melatonin to lower body temperature and negatively affected participants sleep architecture, including increased awakenings, longer time falling asleep, and difficulty entering different stages of sleep. In instances where these disruptions were viewed, participants reported more daytime sleepiness, mood issues, and difficulty with focus and attention, with results 
seen in the post-sleep behavioral tests. The only sleep parameters where higher intensity was a significant factor was in prolonging stage 1 and 2 sleep $(\mathrm{I}=5.17$ and $\mathrm{I}=5.71$ both at $\mathrm{p}<0.05)$ and slow wave sleep ( $\mathrm{I}=4.54, \mathrm{p}<0.05)$. At $(\mathrm{p}<0.001)$ shorter wavelength independently had more significance when it came to total sleep time ( $\mathrm{W}=$ $21.45)$, stage 1 sleep $(W=17.9)$, stage 2 sleep $(W=14.03)$, sleep efficiency percent $(\mathrm{W}=24.5)$, awakening index $(\mathrm{W}=$ 18.3), and slow wave sleep percent ( $W=42.55)$. Overall, this study explained that blue light was the greatest contributing factor of negative sleep effects. These results led to participants feeling more irritable, less focused, and sleepier during the day ${ }^{21}$. This study provides evidence that exposure to blue light creates negative physiological effects. More studies need to be performed to determine in depth effects of blue light on physiological development.

Other physical problems can be initiated and exacerbated by increased cell phone use such as trigger thumb and text neck syndrome. According to Dr. Arush Patel, an orthopedic surgeon specializing in hand surgery, trigger thumb, or stenosing tenosynovitis, is when the thumb becomes stuck in the bent position and pops when attempting to straighten it, which causes increased inflammation that can eventually lead to loosing range of motion $^{49}$. Dr. Robert Wysocki, an orthopedic specialist at Rush University Medical Center, explained that repeated gripping such as tightly holding a cell phone or texting can cause trigger thumb ${ }^{7}$. Several case studies were reported where activities leading up to a diagnosis of tenosynovitis or tendinitis in the thumb were directly related to texting or using thumbs repetitively on a touch screen ${ }^{3,8,70}$. Researchers at M V Shetty College of Physiotherapy reviewed 10 studies with participants experiencing smartphone induced neck pain due to text neck posture. According to these investigators, text neck was coined by Dr. DL Fishman, a chiropractor, and involves strain, tightness, and spasms in the neck or nerve pain in the back, shoulders, or arms from spending too much time looking down at a cell phone. The researchers included cohort and cross-sectional surveys and controlled randomized trials and found that when the neck slants forward over the shoulders, weight is added to the spine. This weight forces the muscles in the neck and shoulder areas to work harder than they should, thereby causing pain. The amount of cell phone use positively correlates with flexibility and poor posture. They also determined that the longer subjects used their smartphones, the more the neck flexion angle increases, thereby putting more pressure on the spine. They explained that progressively, this posture can lead to broken or degenerative discs ${ }^{45}$. One cross sectional study analyzed the data received from 500 questionnaires of healthy male (166) and female (334) university students (average age 21.5 years) between February and March of 2017. They found using the Pearson correlation of 0.14 , that neck pain severity was increased with increased duration of cell phone use $(p=0.001)^{2}$. More research needs to be performed to compare body positions while using mobile phones in relation to the amount of neck pain. This research does add to the negative physical effects caused by increased cell phone use.

\section{Mental and Physical Health}

\section{Addiction and Brain Changes}

The Diagnostic and Statistical Manual of Mental Disorders (DSM-5) defines addiction in terms of gambling or substance use. Contributors analyze the following criteria to help determine a diagnosis of addiction: control, tolerance, safety, preoccupation, time spent, amount of interference in social or occupational functioning and the ability to stop ${ }^{5}$. Occasionally, cell phone use can become unbalanced. The aforementioned Screen Education Survey revealed that $65 \%$ of teens wished they were able to limit the time they spend on their phone and $32 \%$ want to stop using their cell phone, but find it too difficult to do so. Also, $30 \%$ of teens reported that they missed opportunities to do something they desired simply because they spent too much time on their phone ${ }^{59}$. The DSM-5 has only recognized compulsive gambling as a disorder of behavioral addiction, but behaviors such as internet gaming (one of the many cell phone activities) needs more research to be considered an addiction ${ }^{5}$. Gutiérrez, Rodríguez de Fonseca, and Rubio (2016) explain that these behaviors are better defined as impulsive behaviors and representative of psychopathological personality traits rather than true addictive disorders, according to contributors of the DSM- $5^{23}$. These researchers created a chart comparing problematic cell-phone use versus DSM-5 criteria of substance use disorder and gambling disorder (see Table 1$)^{23}$.

Although cell phone or social media addiction is not yet recognized, brain changes have been viewed in those who score high on scales that measure cell phone use. The Mobile Phone Addiction Index (MPAI) is a five-point Likert scale that measures four addiction symptoms: control, anxiety and craving, escape and withdrawal, and productivity loss. It analyzes these symptoms regarding boredom, sensation seeking and self-esteem, in relation to mobile phone use ${ }^{34}$. A group of analysts examined magnetic resonance imaging (MRI) in 68 college students who scored high on the Mobile Phone Addiction Index (MPAI) and compared them to a control group. They found that those who scored high on this scale had significantly less gray matter volume and white matter integrity than the controls ${ }^{69}$. The gray matter is the part of the brain that is responsible for information processing of the senses and transporting nutrients and energy to the neurons. White matter sends this information to and from the gray matter 
Table 1: Summarized comparison criteria of problematic cell-phone use vs. DSM-5 criteria for compulsive gambling and substance use

\begin{tabular}{|c|c|c|}
\hline Problematic Cell-Phone Use & DSM-5 Criteria-Substance Use Disorder & DSM-5 Criteria for Gambling Disorder \\
\hline 1. Use in dangerous or prohibited contexts & $\begin{array}{l}\text { 1. Dangerous use/performance problems in } \\
\text { work, social or leisure activities }\end{array}$ & 1. Turns to loans when money runs out \\
\hline $\begin{array}{l}\text { 2. Social \& family conflicts/loss of interest in } 2 \\
\text { other activities }\end{array}$ & $\begin{array}{l}\text { 2. Social, interpersonal problems related to } \\
\text { use/abandonment of usual activities due } \\
\text { to use }\end{array}$ & $\begin{array}{l}\text { 2. Personal and social relationships, job } \\
\text { studies, etc. in danger or are lost }\end{array}$ \\
\hline $\begin{array}{l}\text { 3. Continuing behavior despite awareness } \\
\text { of negative effects in self and others and } \\
\text { personal malaise it causes }\end{array}$ & $\begin{array}{l}\text { 3. Continuing use despite awareness of mental/ } \\
\text { physical problems caused or exacerbated } \\
\text { by use }\end{array}$ & 3. $\mathrm{k}$ \\
\hline 4. Difficulty controlling & 4. Repeated attempts to quit & 4. Repeated unsuccessful efforts to avoid \\
\hline $\begin{array}{l}\text { 5. Frequent \& constant checking of phone in } \\
\text { very brief periods with insomnia \& sleep } \\
\text { disturbance }\end{array}$ & $\begin{array}{l}\text { 5. Spending a lot c } \\
\text { using, or reco } \\
\text { substance }\end{array}$ & $\begin{array}{l}\text { 5. Excessive preoccupation (means to g } \\
\text { money, memories of experience } \\
\text { continued gambling) }\end{array}$ \\
\hline $\begin{array}{l}\text { 6. Tolerance/increase in use to achieve } \\
\text { satisfaction or relaxation or to counteract a } 6 \\
\text { dysphoric mood }\end{array}$ & 6. $\mathrm{T}$ & $\begin{array}{l}\text { 6. Growing need to gamble a progressively } \\
\text { increasing amt. of money to achieve } \\
\text { well-being }\end{array}$ \\
\hline $\begin{array}{l}\text { 7. Excessive use, need to be connected, sense } \\
\text { of urgency in responding to messages, } \\
\text { preferring phone to personal contact }\end{array}$ & 7. Pros & $\begin{array}{l}\text { 7. Search for gambling opportunities when } \\
\text { anxious, depressed, uneasy, powerless, } \\
\text { etc. }\end{array}$ \\
\hline $\begin{array}{l}\text { 8. Abstinence, dependence, craving, anxiety, } \\
\text { irritability, or unease if not able to use cell } \\
\text { phone }\end{array}$ & $\begin{array}{l}\text { 8. Abstinence syndrome-physical effects } \\
\text { withdrawal. }\end{array}$ & $\begin{array}{l}\text { 8. Lies to self, denies dependence, unease } \\
\text { and irritability when trying to stop or } \\
\text { avoid gambling }\end{array}$ \\
\hline
\end{tabular}

Note. Adapted from "Cell-phone addiction: A review," by J.D. Gutiérrez, F. Rodríguez de Fonseca, and D. Rubio, 2016, Frontiers in Psychiatry, 7(175), p. 1-15 (https://doi.org/10.3389/fpsyt.2016.00175). Copyright 2016 by De-Sola Gutiérrez, Rodríguez de Fonseca, and Rubio.

through its axons ${ }^{54}$. Increased cell phone use is changing the structure and function of the brain.

The National Institute of Health (NIH) is currently conducting research in the US to study cognitive brain development in adolescents. It is called the Adolescent Brain Cognitive Development Study (ABCD). More specifically, this group is focusing on impacts of cell phone use in relation to the physical structure of the brain and emotional mental health development. The study was initiated in 2016 and recruited 11,000 adolescents aged 9-10 to be examined during a 10-year period $^{42}$. Although full results are not available yet, initial observations have revealed an increase in the release of the neurotransmitter dopamine while participants used Instagram ${ }^{30}$. Dopamine is released when one engages in pleasurable activities and plays a crucial role in cravings and desires. Increased dopamine levels result in restlessness, distraction, and difficulty sleeping9. Other initial observations in the ABCD study reveal that those who spend 7 hours or more on their cell phones showed signs of premature thinning of the cerebral cortex ${ }^{10}$, which is the thin layer of grey matter that covers each hemisphere of the brain controlling memory, perception, and thought processes. Interference in these areas can lead to issues with problem solving, language, motor movements and social functioning ${ }^{60}$. These observations signify that with increased cell phone use, executive functioning is disturbed.

Nomophobia is essentially the fear of not having one's mobile phone. Two validated tests to help gauge unmanageable cell phone use include The Nomophobia Questionnaire (NMP-Q) and the Smart Phone Addictions Scale short version (SAS-SV) ${ }^{33,71}$. The NMP-Q consists of 20 questions including four qualitative dimensions that rate a lack of: communication, connection, information accessibility, and convenience. It includes a seven-point Likertscale ranging from $20-140$ points. A score of 20 means there is an absence of nomophobia, 21-59 is considered mild nomophobia, 60-99 is moderate and a score of 100140 suggests severe nomophobia (see Table 2 ) $^{71}$. Kwon et al. $(2013)^{33}$ created a shortened version of the Smart Phone Addictions Scale to help save time and money. The original scale entailed 33 questions that had gender and age limitations. The short version controlled these factors and reduced the test to ten questions (see Table 3 ) $^{33}$. The (SASSV) was determined to have good reliability and validity. A score of 22 or below indicated no addiction and a score of 34 or above indicated a potential addiction. Researchers explain that this scale should be used more as an assessment tool to screen for risk of smartphone addiction rather than used as a diagnostic tool ${ }^{33}$. Since an increased number of the population are using cell phones ${ }^{52}$ and using them more frequently ${ }^{57,66}$, there is a greater potential for cell phone addiction. These tests could contribute to the assessment of the actual prevalence of problematic cell phone use in future controlled studies. They could also aid in identifying addiction and helping individuals curb this growing problem. 
Table 2

\section{Nomophobia Questionnaire (NMP-Q)}

I would feel uncomfortable without constant access to information through my smartphone.

I would be annoyed if I could not look information upon my smartphone when I wanted to do so.

Being unable to get the news (e.g. happenings, weather, etc.) on my smartphone would make me nervous.

I would be annoyed if I could not use my smartphone and/or its capabilities when I wanted to do so.

Running out of battery in my smartphone would scare me.

If I were to run out of credits or hit my monthly data limit, I would panic.

If I did not have a data signal or could not connect to Wi-Fi, then I would constantly check to see if I had a signal or could find a Wi-Fi network.

If I would not use my smartphone, I would be afraid of getting stranded somewhere.

If I could not check my smartphone for a while, I would feel a desire to check it.

If I did not have my smartphone with me, I would feel anxious because I could not instantly communicate with my family and/or friends.

If I did not have my smartphone with me, I would be worried because my family and/or friends could not reach me.

If I did not have my smartphone with me, I would feel nervous because I would not be able to receive text messages and calls.

If I did not have my smartphone with me, I would be anxious because I could not keep in touch with my family and/or friends.

If I did not have my smartphone with me, I would be nervous because I could not know if someone had tried to get a hold of me.

If I did not have my smartphone with me, I would feel anxious because my constant connection to my family and friends would be broken.

If I did not have my smartphone with me, I would be nervous because I would be disconnected from my online identity.

If I did not have my smartphone with me, I would be uncomfortable because I could not stay up to date with social media and online networks.

If I did not have my smartphone with me, I would feel awkward because I could not check my notifications for updates from my connections and online networks.

If I did not have my smartphone with me, I would feel anxious because I could not check my email messages.

If I did not have my smartphone with me, I would feel weird because I would not know what to do.

Note. The NMP-Q has 20 questions, each scored on a 7-point Likert scale. The total score on the NMP-Q is between 20 and 140 . Score interpretation is as follows: 20 = absence of nomophobia, $21-59=$ mild level of nomophobia, $60-99=$ moderate level of monophobia and $100-140$ = severe nomophobia. Adapted from "Exploring the dimensions of nomophobia: Development and validation of a self-reported questionnaire," by C. Yildirim and A Correia, 2015, Computers in Human Behavior, 49, p. 130- 137 (https://doi.org/10.1016/j.chb.2015.02.059). Copyright 2015 by Elsevier Ltd.

Table 3: Smartphone Addiction Scale-Short Version (SAS-SV)

\begin{tabular}{|c|c|c|c|c|c|c|c|}
\hline \multicolumn{2}{|r|}{ Items } & \multirow{2}{*}{$\begin{array}{c}\text { Strongly } \\
\text { disagree }\end{array}$} & \multirow{2}{*}{$\begin{array}{c}\text { Disagree } \\
2\end{array}$} & \multirow{2}{*}{$\begin{array}{c}\text { Weakly } \\
\text { disagree }\end{array}$} & \multirow{2}{*}{$\begin{array}{c}\text { Weakly } \\
\text { agree }\end{array}$} & \multirow{2}{*}{$\begin{array}{c}\text { Agree } \\
5\end{array}$} & \multirow{2}{*}{\begin{tabular}{|c}
$\begin{array}{c}\text { Strongly } \\
\text { agree }\end{array}$ \\
6
\end{tabular}} \\
\hline 1 & Missing planned work due to smartphone use & & & & & & \\
\hline 2 & $\begin{array}{l}\text { Having a hard time concentrating in class, while doing assignments, } \\
\text { or while working due to smartphone use }\end{array}$ & 1 & 2 & 3 & 4 & 5 & 6 \\
\hline 3 & $\begin{array}{l}\text { Feeling pain in the wrists or at the back of the neck while using a } \\
\text { smartphone }\end{array}$ & 1 & 2 & 3 & 4 & 5 & 6 \\
\hline 4 & Will not be able to stand not having a smartphone & 1 & 2 & 3 & 4 & 5 & 6 \\
\hline 5 & Feeling impatient and fretful when I am not holding my smartphone & 1 & 2 & 3 & 4 & 5 & 6 \\
\hline 6 & Having my smartphone in my mind even when I am not using it & 1 & 2 & 3 & 4 & 5 & 6 \\
\hline 7 & $\begin{array}{l}\text { I will never give up using my smartphone even when my daily life is } \\
\text { already greatly affected by it }\end{array}$ & 1 & 2 & 3 & 4 & 5 & 6 \\
\hline 8 & $\begin{array}{l}\text { Constantly checking my smartphone so as not to miss conversations } \\
\text { between other people on Twitter or Facebook }\end{array}$ & 1 & 2 & 3 & 4 & 5 & 6 \\
\hline 9 & Using my smartphone longer than I had intended & 1 & 2 & 3 & 4 & 5 & 6 \\
\hline 10 & The people around me tell me that I use my smartphone too much & 1 & 2 & 3 & 4 & 5 & 6 \\
\hline
\end{tabular}

Note. Adapted from "The smartphone addiction scale: Development and validation of a short version for adolescents," by M. Kwon, D-J. Kim, H. Cho and S. Yang, 2013, PLOS ONE, 8(12), (https://doi.org/10.1371/journal.pone.0083558). Copyright 2013 by Kwon et al.

\section{Role-Modeling}

Role-modeling is crucial in infant development of attitudes and behaviors. The Still Face Paradigm was a theory presented in 1975 to the Society for Research in Child Development (SRCD) by Edward Tronick, Ph.D. It suggested that children have detrimental effects when parents model unresponsive or emotionless affect. In this same proposal the researchers presented a videotape of a mother playing with her 70-day old infant in a car seat, as she normally would, look away for a moment, then 
look back at her infant with an expressionless stare for three minutes ${ }^{1}$. Stages of this paradigm were analyzed by Tronick in a video used as a reference for the court system in $2007^{28}$. He interprets these stages in an excerpt from this video on YouTube. Tronick states that the infant smiles at first to try and engage the mother; then points to get the mother to look; later reaching out with both hands and screeching to get the mother's attention; next, looking away and changing posture; and finally matching the mother's expression with a flat affect, giving up, and then starting to $\mathrm{cry}^{27}$. This work created interest for several follow up studies manipulating different variables of the still face effect ${ }^{1}$. The Still Face Paradigm was modified by Hunter College and The Graduate Center at the City University of New York by using mobile devices during the 'still face' portion of the experiment. Researchers created three hypotheses. The first was that since mobile device use appears to mirror the disengaged effect of the still face phase of the original paradigm, the infant would demonstrate larger negative affect and a smaller positive affect during this phase as compared to the free play and reunion phase of the experiment. Next, they hypothesize that if the mother's general mobile device use is greater, then the infant will be more accustomed to less emotional responses and show fewer negative responses during the still face phase. The third hypothesis suggests that infants with a generally high negative affect would be more disruptive during the still face phase and not as engaging during the reunion phase. Questionnaires were given to mothers to determine frequency of mobile device use, type of use (in front of family and/or infant), how many forms of use (e.g. texting and emailing) and temperament of their infant (4-12 months) or toddler (12-24 months). Two validated temperament tests were used where subscales were joined after creating z-scores within the questionnaires to measure temperament of the entire age range of child participants. No significant differences were found in temperament z-scores between these two tests (ps $>0.10$ ). Fifty infants with an average age of 15.4 months were observed with their mothers under the following three phases: (1) normal free play (FP) between mother and child; (2) still face (SF), where the mother becomes emotionally unresponsive while using her cell phone; and (3) the reunion phase (RU) where normal play continues. Three raters coded each child's behavior based on negative affect (negative facial expressions, protesting, vocalizing, or withdrawing), positive affect (joyful facial expression, smiling, positive vocalizing tone), toy engagement, social bid for attention, and room exploration. Age and sex were controlled where no differences of temperament were evident between males and females (ps $>0.10$ ), SF child behavior (ps $>0.10$ ), or maternal mobile habits ( $p s>0,10$ ). The study revealed comparable results to the original Still Face experiment in that there were more observations of negative affect and less observations of positive affect during the Still Face phase and more positive affect in the Free Play and Reunion phases. Toy engagement and interaction with the mother was observed more in FP versus SF, social bids for the mother's attention were more in $\mathrm{SF}$ than in FP, and infant room exploration was more during the SF as opposed to the RU. The authors concluded that disengagement from the parent while using a mobile device mimics the Still Face Paradigm which results in reducing the positive quality of infant's social-emotional functioning. Further long-term follow-up studies would need to be performed to determine the impact of parental mobile use on children's social emotional regulation in later stages of development ${ }^{40}$. These results help to remind parents and caretakers that children model behavior, so it is important to monitor and reduce cell phone use while spending time with children.

\section{Nonverbal Communication}

According to Dr. Jurgen Ruesch and author Weldon Kees, who studied visual perception, nonverbal communication is the process of sending and receiving messages without spoken or written words ${ }^{56}$. Researchers at the University of California, Los Angeles created a field experiment to test how the absence of screens (cell phones, television, and video games) influences the ability to understand nonverbal emotional cues. The study was composed of 105 boys and girls with ages ranging between 11 and 13 years old. The participants were separated into two groups: the control group, who stayed at school and the experimental group, who went to a five-day nature camp that prohibited the use of television, computers, and mobile phones. All participants completed tests on the Monday before the retreat and the Friday after the retreat. The two validated pre- and posttests included the second edition of the Diagnostic Analysis of Nonverbal Behavior (DANVA2) Faces subtest and the Child and Adolescent Social Perception Measure (CASP). The DANVA2 incorporated 48 faces of varying intensities of emotional expression that were viewed for two seconds each. The participants had to record the type of emotion they interpreted. The CASP included ten videos, five pre-test and five post-test videos. These videos involved children and adults acting out typical adolescent school and home scenarios. The participants had to judge emotional states of the actors. The results reported significance in the experimental group compared to the control group. The experimental group had an average of 14.02 errors in the DANVA2 pretest and 9.41 in the post-test, where the control group had an average of 12.24 pretest errors and 9.81 post-test errors. The experimental group significantly improved their facial emotion interpretation compared to the control group ( $\mathrm{F}$ $(5,88)=4.06, p<0.05, d=0.33)$. With the CASP test, the experimental group improved their ability to interpret 
emotion and was significantly better than the control group $(\mathrm{F}(5,86)=8.75, \mathrm{p}<0.01, \mathrm{~d}=0.66)$. Researchers concluded that in the absence of screens, adolescents' ability to read human emotion improves ${ }^{68}$. This study provides hope to those who have noticed decreased affect recognition due to increased cell phone use.

\section{Technoference, Cognition, and Behavior}

Dr. Brandon McDaniel, a family scientist at Illinois State University, coined the term "technoference" and defines it as "everyday interruptions in interpersonal interactions or time spent together that occur due to digital and mobile technology devices"35. An investigative study included 170 families in the United States (US) using parent self-reports to study how technoference influenced internal and external problematic behaviors in young children. These problems were defined according to the Achenbach Child Behavior Checklist. Internalizing behaviors included anxiety, depressive state, withdrawal, and somatic complaints while externalizing problems included aggressive or rule-breaking behavior. Researchers concluded there were significantly more internalizing and externalizing behaviors with increased technoference ${ }^{36}$. Technoference can lead to learning difficulties which is illustrated in the following study.

Reed, Hirsh-Pasek, and Golinkoff (2017) $)^{53}$ investigated how infant learning is affected by cell phone interruptions. Thirty-eight mothers were instructed to teach their two-year-old toddlers two new words: 'frep' and 'blick.' Frep was instructed to mean a modified type of shaking demonstrated on a maraca. Blick was considered a modified type of bouncing and demonstrated on a doll. One word was interrupted by a 30 second cell phone call while the other word was not. A 30 second phone call separated the teaching session of the two words. The testing phase included Sesame Street characters acting out these different behaviors. Toddlers were instructed to decide which action was a frep and which one was a blick. The authors reported that statistical significance in learning was only found with comprehension of words without interruptions $\left(F(1,34)=6.44, p<0.02\right.$, partial $\left.\eta^{2}=0.16\right)$. Children comprehended the meaning when teaching was not interrupted $(\mathrm{M}=0.63)$ compared to interruptions ( $\mathrm{M}$ $=0.50$ ). The researchers concluded that learning in twoyear-old toddlers is best when teaching is not interrupted by cell phone calls ${ }^{53}$. Additional initial observations from the ABCD study mentioned earlier revealed that those participants who spent at least 2 hours on their phones scored lower on thinking and language tests than those who spent less than 2 hours ${ }^{10}$. The evidence captures how increased use by cell phones negatively impacts the ability to learn.

\section{Multitasking}

Multitasking is when one engages in more than one task at a time ${ }^{38}$. One study investigated distraction, memory, and switching tasks between two groups of cell phone users ${ }^{47}$. The researchers created a trait media multitasking index to signify heavy media multitaskers (HMM) and light media multitaskers (LMM). The results revealed that those determined to be HMM had significantly more difficulty than the LMM in filtering irrelevant pieces of memory, filtering distraction and switching to different tasks. These results demonstrated that the more one multitasks on cell phones, the more there is indication of interference with information processing, increased errors, and decreased quality of an activity ${ }^{47}$. According to the Screen Education survey $49 \%$ of teens feel that their smartphone shortens their attention span and $56 \%$ of teens go online daily with the intention of doing one thing but get sidetracked doing something else for an extended period. Of those surveyed, $41 \%$ feel that their phone is an obstacle to getting the best grades they can in school ${ }^{59}$.

Multitasking has been a significant factor in car crashes. In 2017 the latest published data from the US Department of Transportation, National Highway Traffic Safety Administration reports that, 2,994 distracted drivers were involved in fatal car crashes and 3,166 people were killed in these crashes in that year ${ }^{41}$. The Department of Motor Vehicles reported that approximately $\mathbf{6 6 0 , 0 0 0}$ drivers in 2017 used their cell phones while driving and $14 \%$ of all crashes that were fatal involved a cell phone. When multitasking increases, especially while driving, deadly accidents can occur ${ }^{12}$. The Screen Education survey reported that $52 \%$ of teens feel compelled to talk on the phone while on the road and 32\% admitted to texting while driving ${ }^{59}$. Adolescence is a critical time for growth and development for the brain and body. Along with hormone levels changing, abstract reasoning, response inhibition, and ability to shift attention improves with age $^{55}$. Although abstract reasoning is developed by age 16, poor choices are still made at this age. The part of the brain that controls impulses, dorsal lateral prefrontal cortex, is not fully developed until the early $20 \mathrm{~s}^{19}$. Multitasking while driving is dangerous for any age group, but adolescents appear to be more susceptible to distraction due to this underdeveloped part of the brain. More studies including multitasking with different age groups would be warranted to support this claim.

\section{Resources and Recommendations for Balance}

Practicing balance from an early age could prevent addiction in later years. One resource to help promote cell phone balance is the website for The American Academy of Pediatrics. They recommend setting limits with cell phones by creating no phone zones, no phone times, 
device curfews, cyberbullying discussions, and limiting time spent on recreational sites. These suggestions are aimed at the adults and kids alike. This organization helps promote more connection between the parent and child by encouraging families to watch or play on the cell phone together rather than alone $e^{4}$. In regard to cyberbullying, Arizona State University devised the BullyBlocker app, which aims to block bullies, report them to authorities, and record them in the act. It also provides information to the user (parent or child) to calculate risk factors of being bullied based on key words used ${ }^{22}$. Although this app has potential to help, victims may be intimidated using it for fear of being exposed to their perpetrator. More research needs to be performed to validate the efficacy of this app.

Some educators suggest teaching cell phone etiquette to students and teachers to promote balance in and out of the classroom ${ }^{46}$. Since cell phones have resulted in distraction and poor sleep, they should be put away when reading a book, having a conversation, and driving a car, and should be kept out of the bedroom ${ }^{31}$. Other potential strategies include teaching cell phone use as analogous to nutrition, where chores, homework, or other priorities need to be completed before using the phone for leisure use. Some suggest encouraging device-free time each day rather than taking a device away. Healthy balance could be achieved by having more parent involvement helping their children to decipher differences between productive screen-time that is educational versus recreational screen time ${ }^{39}$.

Professors at San Francisco State University suggest maximizing mental alertness by scheduling uninterrupted time to do tasks that need more concentration such as creative work or homework, while saving social media for time when less attention is required ${ }^{51}$. Even though these ideas are linked to the use of general computerized devices, the suggestions apply to cell phone and social media use for the purposes of this paper. Since cell phones are smaller and more portable, there is easier access in logging onto social media. Although these strategies have not been thoroughly studied, they could be potential areas for future research.

\section{Conclusion}

Evidence from this literature review has demonstrated that improper use of a cell phones and social media lead to negative effects on health and well-being. Trends have indicated the integration of cell phones into many areas of daily life. Exclusion in social media and cyberbullying have interfered in one's vital need for connection and acceptance, which has led to anxiety, loneliness, depression, and sometimes suicide. In addition, cell phone distraction between parent and child, has resulted in teaching and learning deficits, interference in social development, influencing behavior, and disturbing bond formation between the parent and child. The physiological effects reviewed include structural brain and neurotransmitter changes, trigger thumb and neck pain, and sleep interference from those who use devices improperly or have cell addiction tendencies. Sleepiness paired with cell phone multitasking while driving increases distraction and have led to more car crashes. Educating society and practicing cell phone etiquette is paramount in reducing problems with cell phone use and essential in creating balance.

\section{Acknowledgement}

Acknowledgement is given to Dissertation Editor, LLC, especially Dr. William Caskey, former Managing Editor, and Dr. Patrick Ryan, Editor.

\section{References}

1. Adamson LB, Frick JE. The still face: A history of a shared experimental paradigm. Infancy. 2003; 4(4), 451-473. doi.org/10.1207/ S15327078IN0404_01

2. Al-Hadidi F, Bsisu I, AIRyalat SA, et al. Association between mobile phone use and neck pain in university students: A cross-sectional study using numeric rating scale for evaluation of neck pain. PLoS ONE. 2019; 14(5), e0217231. https://doi.org/10.1371/journal. pone.0217231

3. Ali M, Asim M, Danish SH, et al. Frequency of De Quervain's tenosynovitis and its association with SMS texting. Muscles Ligaments Tendons J. 2014; 4(1):74-78. Published 2014 May 8. https://www. pubmed.ncbi.nlm.nih.gov/24932451/

4. American Academy of Pediatrics. Family Media Plan. Text Request. 2020. https://www.healthychildren.org/English/media/Pages/default.aspx.

5. American Psychiatric Association. Diagnostic and statistical manual of mental disorders ( $5^{\text {th }}$ ed.). Washington, DC. American Psychiatric Association. 2013.

6. Andrew 0. The history and evolution of the smartphone: 1992-2018. Text Request. 2018; August 28. https://www.textrequest.com/blog/ history-evolution-smartphone/

7. Asa R. "Smartphone thumb" and "texting thumb" injuries. YourCareEverywhere. 2015; September 2. https://www. yourcareeverywhere.com/health-research/health-insights/paincare-insights/_smartphone-thumb-injuries-are-on-the-rise.html

8. Ashurst JV, Turco DA, Lieb BE. Tenosynovitis caused by texting: An emerging disease. J Am Osteopath Assoc. 2010; 110(5): 294-296. https://www.jaoa.org/article.aspx?articleid=2094077

9. Ayano G. Dopamine: Receptors, functions, synthesis, pathways, locations and mental disorders: Review of literatures. J Ment Disord Treat. 2016; 2(2), 1-4. https://doi.org/10.4172/2471-271X.1000120

10. Bell V. Children who spend seven hours or more on smartphones and tablets. Daily Mail Online. 2018; December 10. http://www.dailymail. co.uk/sciencetech/article-6477685/Heavy-screen-time-appearsimpact-childrens-brains-study.html

11. Bian M, Leung L. Linking loneliness, shyness, smartphone addiction symptoms, and patterns of smartphone use to social capital. Social Science Computer Review. 2014; 33(1), 61-79. https://doi. org/10.1177/0894439314528779

12. Clerkin B. Death by text message? Stats show how technology is killing us. Department of Motor Vehicles. April 28, 2017. https://www.dmv. org/articles/death-by-text-message-stats-show-how-technology-iskilling-us/ 
13. Croughs $\mathrm{W}$. The influence of emotional deprivation on growth and behaviour. In Stoelinga G. B. A., \& Van Der Werff Ten Bosch J. J. (Eds.), Normal and Abnormal Development of Brain and Behaviour. 1971; Vol 6., pp. 271-283. https://doi.org/10.1007/978-94-010-2921-6_17

14. Davuluri N. The story of Ryan Halligan. The Carson Chronicle. 2016; November 22. https://carsonchronicle.com/2818/events/the-storyof-ryan-halligan/

15. Dean M. The story of Amanda Todd. The New Yorker. 2012; October 8. https://www.newyorker.com/culture/culture-desk/the-story-ofamanda-todd

16. Dyroff C. Here's how much cellphones have actually changed over the years. Insider. 2018; July 25. https://www.insider.com/the-historyof-the-cellphone-2018-7

17. Eisenberger NI, Lieberman MD, Williams KD. Does rejection hurt? An fMRI study of social exclusion. Science.2003; 302(5643), 290-292. https://doi.org/10.1126/science.1089134

18. Gibbs N. Your Life is Fully Mobile. Time. 2012; August 16. http:// techland.time.com/2012/08/16/your-life-is-fully-mobile/

19. Giedd JN. Structural magnetic resonance imaging of the adolescent brain. Ann NY Academy of Science. 2004; 1021(1), 77-85https://doi. org/10.1196/annals.1308.009

20. Gradisar M, Wolfson AR, Harvey AG, et al. The sleep and technology use of Americans: findings from the National Sleep Foundation's 2011 Sleep in America Poll. J Clin Sleep Med. 2013; 9(12):1291-1299. https://doi.org/10.5664/jcsm.3272

21. Green A, Cohen-Zion M, Haim A, et al. Evening light exposure to computer screens disrupts human sleep, biological rhythms, and attention abilities. Chronobiology International. 2017; 34(7), 855-865. https://doi.org/10.1080/07420528.2017.1324878

22. Greguska E. BullyBlocker an interdisciplinary effort, goes beyond abilities of other apps by combining risk factors with keywords to alert parents. ASU Now. 2017; September 20. https://asunow.asu. edu/20170920-solutions-asu-team-takes-cyberbullying-app-public

23. Gutiérrez JD, Rodríguez de Fonseca F, Rubio D. Cell-phone addiction a review. Frontiers in Psychiatry. 2016; 7(175), 1-15. https://doi. org/10.3389/fpsyt.2016.00175

24. Hinduja S. Smartphone apps and bullying. Cyberbullying Research Center. 2012; November 5. https://cyberbullying.org/smartphoneapps-and-bullying

25. Hinduja S, Patchin JW. Cyberbullying identification, prevention, and response. Cyberbullying Research Center. 2020. https://cyberbullying. org/Cyberbullying-Identification-Prevention-Response-2020.pdf

26. Holt-Lunstad J, Smith TB, Layton JB. Social relationships and mortality risk: a meta-analytic review. PLoS Med. 2010; 7(7), e1000316. https:// doi.org/10.1371/journal.pmed.1000316

27. Hudson L, Lovett JF. Lovett Productions'. Still Face Experiment: Dr. Edward Tronick [Video]. YouTube. 2009; November 30. https:// youtube.com/watch?v=apzXGEbZht0

28. Hudson L, Lovett JF. (Producers). Helping babies from the bench:Using the science of early childhood development in court. Washington, DC: Zero To Three. 2007. https://lovettproductions.com/portfolio/zeroto-three/

29. Jaffe E. Why it's so hard to detect emotion in emails and texts. Fast Company. 2014; October 9. https://www.fastcompany.com/3036748/ why-its-so-hard-to-detect-emotion-in-emails-and-texts

30. Kindler S. Does long screen time affect a child's brain? Let's find out. Peace Quarters. 2019; December 19. https://www.peacequarters. com/long-screen-time-effect-a-childs-brain/

31. Klass P. Five no-phone- zones for parents and kids alike. New York Times. 2017; January 23. https://nyti.ms/2kj7oVV
32. Kruger J, Epley N, Parker J, et al. Egocentrism over e-mail: can we communicate as well as we think? Journal of Personality and Social Psychology. 2005; 89(6) 925-936. https://doi.org/10.1037/00223514.89.6.925

33. Kwon M, Kim D-J, Cho H, et al. The smartphone addiction scale: development and validation of a short version for adolescents. PLoS ONE. 2013; 8(12). https://doi.org/10.1371/journal.pone.0083558

34. Leung L. Linking psychological attributes to addiction and improper use of the mobile phone among adolescents in Hong Kong. Journal of Children and Media. 2008; 2(2), 93-113. https://doi. org/10.1080/17482790802078565

35. McDaniel BT. "Technoference": Everyday intrusions and interruptions of technology in couple and family relationships. In C. J. Bruess (Ed.), Family communication in the age of digital and social media. 2015; (pp. 1-18). New York: Peter Lang Publishing.

36. McDaniel BT, Radesky JS. Technoference: parent distraction with technology and associations with child behavior problems. Child Development. 2017; 89(1), 100-109. https://doi.org/10.1111/ cdev.12822

37. Mercado MC, Holland K, Leemis RW, et al. Trends in emergency department visits for nonfatal self-inflicted injuries among youth aged 10 to 24 years in the United States, 2001-2015. JAMA. 2017; 318(19), 1931-1933. https://doi.org/10.1001/jama.2017.13317

38. Merriam-Webster. (n.d.). Multitasking. In Merriam-Webster. com dictionary. https://www.merriam-webster.com/dictionary/ multitasking

39. Moss-Coane M. Radio times kids and screens [Interview]. WHYY FM; Philadelphia, PA. 2019; May 28. https://whyy.org/episodes/kidsand-screens/

40. Myruski S, Gulyayeva 0, Birk S, et al. Digital disruption? Maternal mobile device use is related to infant social-emotional functioning. Dev Sci. 2017; 21(4), e12610. https://doi.org/10.1111/desc.12610

41. National Center for Statistics and Analysis. Distracted driving in fatal crashes, 2017. (Traffic Safety Facts Research Note. Report No. DOT HS 812 700). Washington, DC: National Highway Traffic Safety Administration. 2019; April. https://crashstats.nhtsa.dot.gov/Api/ Public/ViewPublication/812700

42. National Institute of Mental Health. Adolescent brain cognitive development (ABCD) study. National Institute of Health. 2016; August. https://www.nimh.nih.gov/research/research-funded-by-nimh/ research-initiatives/adolescent-brain-cognitive-development-studyabcd-study.shtml

43. National Sleep Foundation. How electronics affect sleep. 2020. https://www.sleepfoundation.org/bedroom-environment/see/ how-electronics-affect-sleep

44. National Sleep Foundation. National Sleep Foundation 2011 sleep in America poll: communications technology in the bedroom. 2011. https://www.sleepfoundation.org/wp-content/uploads/2018/10/ SIAP_2011_Summary_of_Findings_0.pdf?x60521

45. Neupane S, Ali UT, Mathew A. Text neck syndrome-systematic review. Imperial Journal of Interdisciplinary Research. 2017; 3(7), 141-148. https://pdfs.semanticscholar.org/ b 2e 5 /d 8 b0 88893 f 8 ac 754 f 70 ede 90 a 036 ed 519365 .pdf? ga $=2.9538294 .278599186 .1579027310-2037896217.1579027310$

46. Nielsen L, Webb W. Teaching generation text: using cell phones to enhance learning. Jossey-Bass. 2011.

47. Ophir E, Nass C, Wagner AD. Cognitive control in media multitaskers. PNAS Journal.2009; 106(37),15583-15587.https://doi.org/10.1073/ pnas.0903620106

48. Patchin JW, Hinduja S. Cyberbullying facts. Cyberbullying Research Center. 2019. https://cyberbullying.org/facts 
49. Patel A. Trigger finger (stenosing tenosynovitis). Arthritis Health 2018; March 15. https://www.arthritis-health.com/types/general/ trigger-finger-stenosing-tenosynovitis

50. Patterson $\mathrm{CH}$, Hidore SC. The primary prevention of psychosocial disorders: a person/client-centered perspective. The Person-Centered Journal. 1997; 4(1), 8-17. http://www.sageofasheville.com/primary_ prevention.html

51. Peper E, Harvey R. Digital addiction: increased loneliness, anxiety, and depression. NeuroRegulation. 2018; 5(1), 3-8. http://doi. org/10.15540/nr.5.1.3

52. Pew Research Center. Mobile fact sheet. 2019; June 12. https://www. pewresearch.org/internet/fact-sheet/mobile/

53. Reed J, Hirsh-Pasek K, Golinkoff RM. Learning on hold: cell phones sidetrack parent-child interactions. Developmental Psychology. 2017 53(8), 1428-1436. https://doi.org/10.1037/dev0000292

54. Robertson S. What is grey matter? News Medical Life Sciences. 2018; August 23. https://www.news-medical.net/health/What-is-GreyMatter.aspx

55. Rosso IM, Young AD, Femia LA, et al. Cognitive and emotional components of frontal lobe functioning in childhood and adolescence. Annals of the New York Academy of Sciences. 2004; 1021(1), 355-362. https://doi.org/10.1196/annals.1308.045

56. Ruesch J, Kees W. Nonverbal communication: notes on the visual perception of human relations ( $5^{\text {th }}$ ed.) University of California Press. 1964.

57. Sales N. American girls: social media and the secret lives of teenagers ( $2^{\text {nd }}$ ed.). Penguin Random House. 2017.

58. Sanchez R, Lance N, Levenson E, et al. Woman sentenced to 15 months in texting suicide case. CNN. 2017; August 3. https://www.cnn. com/2017/08/03/us/michelle-carter-texting-suicide-sentencing/ index.html

59. Screen Education Contributors. Teen Smartphone Addiction National Survey 2018. Screen Education. 2018. https://www.screeneducation. org/uploads/1/1/6/6/116602217/teen_smartphone_addiction_ national_survey_2018_report_6.21.18_upload_version_1.2.pdf

60. Shiel WC, Jr. Medical definition of cerebral cortex. MedicineNet. 2018; December 27. https://www.medicinenet.com/script/main/art. asp?articlekey $=11490$

61. Spitz RA. Hospitalism: an inquiry into the genesis of psychiatric conditions in early childhood [Abstract]. The Psychoanalytic Study of the Child. 1945; 1(1), 53. https://doi.org/10.1080/00797308.1945.1 1823126

62. Spitz RA. Hospitalism: a follow up report on investigation described in volume I, 1945. [Abstract]. The Psychoanalytic Study of the Child. 1946; 2(1), 113. https://doi.org/10.1080/00797308.1946.11823540

63. Spitz RA, Wolf KM. Anaclitic Depression [Abstract]. The Psychoanalytic Study of the Child. 1946; 2(1), 313. https://doi.org/10.1080/007973 08.1946.11823551

64. Thealternativepress.com Staff. Ryan's story: 'Bullying, cyberbullying and youth depression.'TAP into Warren. 2013; November 21. https:// www.tapinto.net/towns/warren/sections/education/articles/ ryans-story-bullying-cyberbullying-and-youth

65. Thomason K. How blue light from your phone may be hurting your eyes (and what to do about it). Eye Health. 2017; May 25. https://www. health.com/eye-health/blue-light-eye-strain

66. Twenge JM. Generation me: Why today's young Americans are more confident, assertive, entitled-and more miserable than ever before. New York: Atria Paperback. 2014.

67. Twenge JM, Joiner TE, Rogers ML, et al. Increases in depressive symptoms, suicide-related outcomes, and suicide rates among U.S. adolescents after 2010 and links to increased new media screen time. Clinical Psychological Science. 2017; 6(1), 3-17. https://doi. org $/ 10.1177 / 2167702617723376$

68. Uhls YT, Michikyan M, Morris J, et al. Five days at outdoor education camp without screens improves preteen skills with nonverbal emotion cues. Computers in Human Behavior. 2014; 39, 387-392. https://doi.org/10.1016/j.chb.2014.05.036

69. Wang Y, Zou Z, Song H, et al. Altered gray matter volume and white matter integrity in college students with mobile phone dependence. Frontiers in Psychology. 2016; 7(597), 1-10. https:// doi.org/10.3389/fpsyg.2016.00597

70. Williams IW, Kennedy BS. Texting tendinitis in a teenager: our patient spent 4 hours a day texting and, not surprisingly, developed tendinitis. Simple tips, though, can help patients avoid injury. Journal of Family Practice. 2011; February. 60(2), 66-67. https://www.researchgate. net/publication/49817791_Texting_tendinitis_in_a_teenager

71. Yildirim C, Correia A. Exploring the dimensions of nomophobia: development and validation of a self-reported questionnaire. Computers in Human Behavior. 2015; 49, 130-137. https://doi. org/10.1016/j.chb.2015.02.059 